\title{
English semi-idioms (phraseological terminological units) and their use in fiction and Internet-discourse
}

\author{
Elena Nikulina ${ }^{1 *}$ \\ ${ }^{1}$ Moscow Pedagogical State University (MPGU), 1/1 Malaya Pirogovskaya St, Moscow, 119991, \\ Russian Federation
}

\begin{abstract}
The article is dedicated to the analysis of the units which can function both as terms of various spheres and an idioms, called in the Russian School of Phraseology, semi-idioms. The research shows the high frequency of usage of the units under question in the literary works as well as in the present-day media discourse space. Moreover, the research also raises the problem of introduction of these units to the students through the analysis on English classes that undoubtedly will lead to the students' language awareness. The results of the linguistic experiments are shown in the paper with the conclusion that semi-idioms are quite important for understanding of intraconnection of Terminology and Phraseology sciences.
\end{abstract}

\section{Introduction}

Phraseology, as is well-known, is a branch of linguistics that studies stable wordcombinations with fully or partially metaphorical meaning. The definition of a phraseological unit suggested by a Russian linguist A.V. Kunin is accepted by most of the scientists. According to his definition "a phraseological unit is a fixed combination of lexemes with fully or partially transferred meaning", however, as the scientists states opinions on the question of fixedness differ and the most widely accepted definition of fixedness among scientists is the ability to apply a "ready-made" phraseological unit [1]. In his English-Russian Phraseological Dictionary (1984) A.V. Kunin pointed out the so-called semi-idioms were included and described. As Kunin put it in the preface of the dictionary, "semi-idioms have both literal and transferred meaning, the first meaning being usually terminological or professional and the second transferred" [2]. The examples of these semi-idioms are as follows: a dark horse - a racing term and an idiom meaning a person who surprises people by doing something nobody expects, to sail too close to the wind - a nautical term and an idiom meaning "to risk", acid test - a term from chemistry and an idiom meaning method of proving the truth.

It should be mentioned that, "terminology is integrative: sometimes the terms of some sciences may function in various terminological systems, or even penetrate into the language for general purposes (LGP)" [3]. Thus, the linguistic experiment was provided to show whether students of the English language could state the terminological or metaphorical nature of some semi-idioms, and examples from the Internet as well as from some fiction were submitted to prove the hypothesis of the dual nature of such units. The purpose of this research is to prove the inter-connection of two system and their integration.

\footnotetext{
* Corresponding author: na.nikulina@mpgu.su
} 


\section{Objects and Methods}

\subsection{Terminology and terminological system: one notion or two?}

According to the Russian scientist Vladimir M. Leitchik, any terminological unit is made on the basis of some lexical unit of a certain natural language, in other words any lexical unit of this language is a substrat for a term [4]. In 2009 a book "Terminology Studies. Subject, Methods, Structure" by Vladimir M. Leitchik expanded the periods mentioned: he described profoundly five periods in the development of terminology in Russia, including the preparatory one, but adding two more - they were the forth (the end of 1980s - 1990s) and the fifth (from the end of 1990s - up to now). The scientist had all the grounds to specify the five periods in Russian terminology science so as terminology studies has become one of the paramount branches of knowledge and more and more researches dedicated to various problems in the sphere of term study appeared: as Vladimir M. Leitchik puts it in his book "from 1992 to 2002 in Russia about 50 treatises on terminology problems were published (...). In 2002 - 2004 in this country 16 more books on terminology were issued"'5]. When terminology is analysed a question arises, if there is any difference between terminology and terminological system: indeed, there are some fundamental varieties between terminology and a terminological system: "the first one is gradually being made up together with the corresponding field and the system of notions (...) and does not exist as a completed system; the lexical units which form terminology are not strictly systematic, they form some homonymous, synonymous and polysemantic relationships; author-based terminology is also made up gradually and may be enhanced and verified" [3]. It is essential to mention that in the recent decade a significant part of terminological units of various spheres have been scrutinized and the theory that any term is a word or word combination created for a specific purpose has been once again proved.

\subsection{Phraseology as an important branch of linguistics}

Initially, studies in phraseology were mostly diachronic, and only focused on some phraseological units. However, from the 1990s a new synchronic perspective arose, which better defined the discipline, established its boundaries, and provided a classification or systematization of those units. New research limits appeared, thanks to Corpus Linguistics, more powerful corpus analysis tools, and the Internet [6]. Nevertheless, a well-known method of the phraseological identification is still used quite often, and in various conferences and seminars there appear new points of view as to the stability of units, their ability to expand the meaning or to replace their components.

It is quite important to remember the main characteristics of a phraseological unit: A.V. Kunin considered the issue of fixedness in combination with possible invariants and distinguished between:

"fixedness of application" underlines belonging of a phraseological unit to a people, however individual utterances are able to become widespread and with the time being fixed;

"structural-semantic fixedness" predetermines a phraseological united to be compiled of two or more words/components, and according to the principle of structural-semantic fixedness a phraseological unit structure cannot be a model to creating other equivalent phraseological units;

"semantic fixedness" presupposes the stability of meaning reconsideration, and the existence of the identical meaning and a lexical invariant, existence of phraseological variants and semantic invariants;

"lexical fixedness" is a principle of non-replaceability of the components of a phraseological unit or the possibility to replace them within phraseological variability or structural synonymy, keeping semantic and lexical invariants; 
"syntactic fixedness" makes the order of the components of a phraseological unit stable, within the phraseological variability the word order can be changed in phraseological units [3]. The notion of fixedness of application is a keystone one for this research as the theory of semi-idioms proves that there can be a certain shift of meaning and it is determined mainly by the intention of a speaker to underline a certain concept, moreover the unit, that is presumably a term per se, is used in a non-terminological context. Thus, a unit with a metaphoric meaning, functioning as an idiom, appears.

\subsection{Methods}

Synthesis and analysis, a method of phraseological identification, continuous sampling method, a method of contextual analysis and a method of statistics were applied to the studied material. One of the most important methods is surely a linguistic experiment.

\section{Results}

As we have already mentioned above, phraseological units can be of various nature, they can have several meanings, a special one, being a term and used in the language for specific purposes, and a metaphorical one, functioning as an idiom in some literary work or in the Internet. To investigate the complex nature of the semi-idioms we asked students from various parts of Britain and the USA to answer the questions in a questionnaire where they had to state whether a unit was a term, an idiom, both, or just say "I do not know". Here are some results presents in the diagrams:

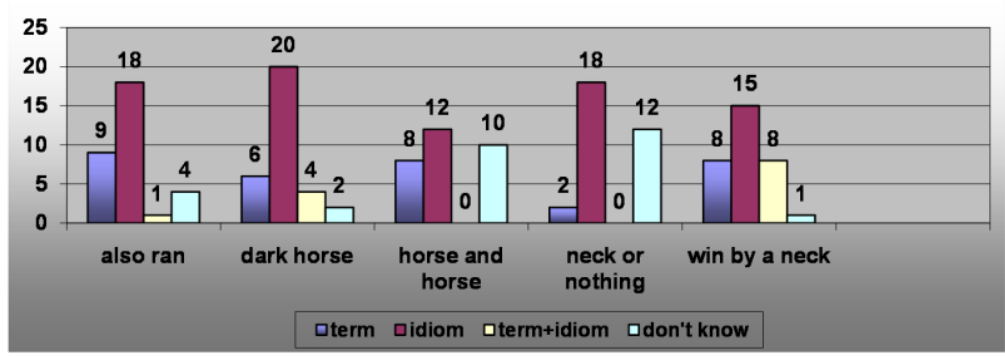

Fig. 1. Analysis of the semi-idioms originated from sports.

As it comes from this diagram, the most well-known semi-idioms turned to be a dark horse, also ran and neck or nothing, a terminological phraseological unit win by a neck was mostly stated as an idiom. Once again it shows the dual form of the unit, though, probably not yet realized. Here are examples of the use of a semi-idiom, dark horse, a vastly used unit:

dark horse: coll a person or thing whose true character or worth is unknown but may be better than is thought (...) referring to a horse in a race, whose ability to win races is unknown [7]

Again Mr. Satterthwaite nodded to himself. Mrs. Dacres was Abrosine Ltd., that successful dressmaking establishment... Her husband, Captain Dacres, was a dark horse in his own racing parlance. He spent a lot of time on race courses - had ridden himself in the Grand National in years gone by. There had been some trouble - nobody knew exactlythough rumours had been spread about little (A. Christie, A Three - Act Tragedy, Ch. I).

"It's not that simple. There's so much overlap, it's hard to tell who's who. The EuroFighter is a mix of French, German, and Brit with some Asian money thrown in. The Lancer is a Brit-only dark horse ..." (B. Norris, Fly-Off, Ch. 7). 
These are the examples from books where the semi-idiom is used to describe human beings, and generally it does not undergo any processes of either changing its structure or the order of components. The only thing that is quite observable here is the meaning - it is not a terminological, but a metaphorical, as the notion of a person nobody knows what to expect of is implied.

Next is a representation of a contest from an Internet issue:

Lloyds share sale: Dark horse, or bad bet?

By Brian Milligan Personal Finance reporter

October 2015

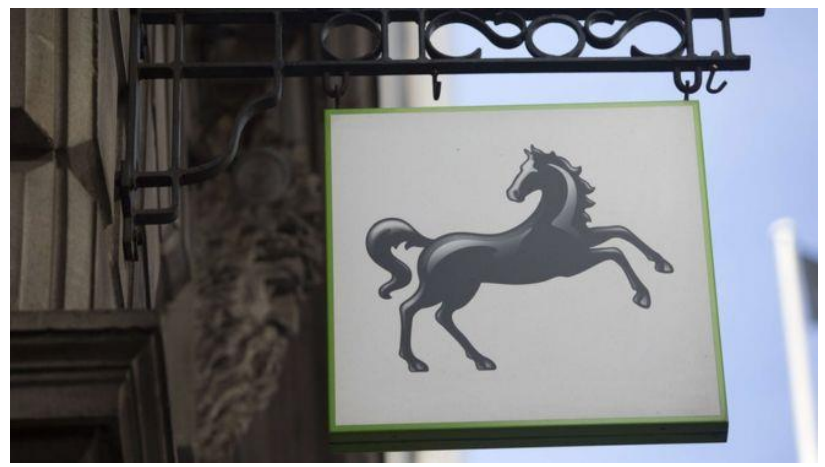

So looking ahead, will Lloyds turn out to be an also-ran, or will it prove the ultimate dark horse?[8]

Here what we see is a double actualization of a metaphoric meaning; dark horse is not only an emblem, a logo of the bank, it is an address to the clients whether to continue to invest in the bank, or to think twice, as nobody knows what could become of the investment. The unit a dark horse here is applied not to a person, but to an institution with unpredictable status. So, the fixedness of application has chaged; the focus is on people, but presumably, the institution of the people.

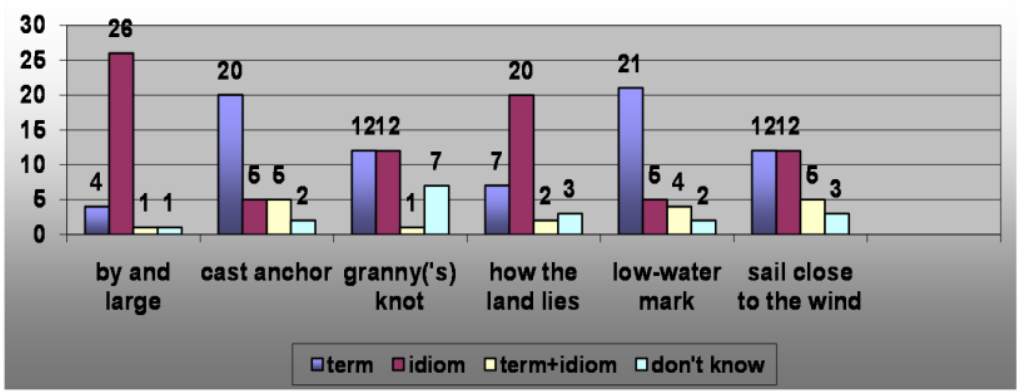

Fig. 2. Analysis of the semi-idioms originated from marine terms.

Here are some examples of the use of the semi-idiom by and large from literary works as well as from the Internet recourses.

by and large: fitfully; with much stopping and starting [9]

In Figure 2, the most important datum is that the semi-idiom by and large is marked as an idiom, though it is a nautical term, still used in various works, both literary, 
After the evening meal was finished and all the bits and pieces put away Anna and I would settle down to some activity ... Fairy stories were dismissed as mere pretended stories; living was real and living was interesting and by and large fun (Fynn, Mister God, This Is Anna, Ch. Two).

and publicistic:

The so-called welfare problem is by and large an ageing population problem Greg Jericho

\section{@ GrogsGamut}

Thu 23 Jan 2014 06.03 GMTLast modified on Tue 13 Mar 2018 17.43 GMT

The article states that “... the government was commissioning a review of the welfare system, brought with it a lot of attention-grabbing figures, but not a great deal of context. The problem with any debates on welfare is they are invariably loaded. The use of "welfare" as a term is itself suggestive that the recipients are getting something for nothing - perhaps even undeserving. Using "government benefits" is not much better [10].So evidently there is not a hint to the nautical nature of the unit, not a word, though it really comes from a term, meaning 'both sailing into the wind' - by - 'and with the wind' - large.

Important syntactic changes, such as substitution of the components, though may be observed in the structure of another semi-idiom, again, of nautical nature, sail close to the wind:

Lombard's own lips parted in a grin. By jove, he'd sailed pretty near the wind once or twice! But he'd always got away with it (A. Christie, Ten Little Niggers, ch. One, III).

"Now, Philip Lombard. Lombard has been mixed up in some very curious shows abroad. He's sailed very near the law once or twice. Got a reputation for daring and for not being an over-scrupulous sort offellow who might do several murders in some quiet outof-the-way spot (A. Christie, Ten Little Niggers, Epilogue).

In the first context one can read about a character from A. Christie's novel, Philip Lombard, who used to contravene the law. The second context explicitly shows that as the lexeme wind has been substituted by the word law.

And the example from the Internet:

Barclays 'continues to sail close to the wind,' says former FPC member.

Threats by Barclays to cut back on lending to households and businesses because of a demand by the Bank of England that it should reduce risks have been criticised by a former policymaker of the central bank.

Robert Jenkins, a former member of the financial policy committee, set up inside the Bank of England look for ticking timebombs in the financial system, said that taxpayers should be concerned that Barclays "continues to sail close to the wind".

The further reading makes it clear that again one of the most powerful bank is risking as it is going to violate the law:

The former FPC member wrote to the Financial Times after the Barclays chief executive, Antony Jenkins, warned a requirement that the bank meet a 3\% leverage ratio could force it to restrict lending. Barclays had to submit a plan to the Bank of England's new banking regulator, the Prudential Regulation Authority, by Sunday to outline how it would raise its ratio from $2.5 \%$ to $3 \%$ - which allows banks to have assets worth 33 times their capital [11]. 
There are no visible changes, apart from the application of the nautical term in its metaphoric use first of all, that evinces the reader's interest and gives the association of breaking the law.

\section{Conclusion}

Semi-idioms, or terminological phraseological units are often used in various texts, sometimes makes the context more intricate, thought the readers do not necessarily associate the units with terms, and more often do not have any reference to terms, as our linguistic experiments shows. Nevertheless, these units are of importance to study not only in terms of their etymology, practicability of changes in their meaning, but mostly for the enlarging the scope of native speakers as well as ESL-speakers. Probably, semi-idioms are so frequently used in literature and the media discourse as they are really picturesque and unusual, they make the dwelling more capturing, thrilling, serving the aim of translation of the main idea onto the readers. So the research could be aimed at a more profound investigation of the functions of semi-idioms in text of different genres, the impact of their usage as well as the structural and componential changes, integrating processes. Deduction of a phraseological meaning sometimes is really impossible without certain cognitive procedures appealing to existence, which is also true about the metaphorical fixed expressions based on the shift of meaning of notions [12]. It is necessary to study terms and phraseological units on the whole to prove the inter-action of these linguistic spheres as language can not be studied separately, it is a means of communication.

\section{Acknowledgments}

This paper was financially supported by the Russian Foundation for Basic Research, grant No. 20-012-22046.

\section{References}

1. A.V. Kunin, Frazeologiya anglijskogo yazyka (Phraseology of the English Language) (Moscow, Mezhdunarodnye otnosheniya, 1972)

2. A.V. Kunin, English-Russian Phraseological Dictionary (Moscow: Russkiy Yazik, 1984)

3. V.M. Leitchik, E.A.Nikulina The Notion Character in Russian Terminology Science. Collected papers from the scientific conference terminology at the time of globilization (Humar, Ljubljana, 2003)

4. V.M. Leitchik, On the language substrat of a term (Moscow, Voprosy yazykoznania 5,1986)

5. V.M .Leitchik, Terminology Studies. Subject, Methods, Structure (Moscow, 2006)

6. M.B.Castro, Phraseology in specialized language and its representation in environmental knowledge resourses, doctoral thesis (Granada, Universidad de Granada, 2013)

7. Longman Dictionary of idioms (Longman, 1992)

8. Lloyds share sale: Dark horse, or bad bet? URL: https://www.bbc.com/news/business$\underline{34444195}$

9. G. Jarvie, Bloomsberry dictionary of idioms (London, A \& C Black, 2009)

10.The so-called welfare problem is by and large an ageing population problem. URL: https://www.theguardian.com/business/grogonomics/2014/jan/23/welfare-problem-an-ageingpopulation-problem

11. Barclays 'continues to sail close to the wind,' says former FPC member. URL: https://www.theguardian.com/business/2013/jul/01/barclays-fpc-robert-jenkins-lending

12. Anna V. Dengina, Elena F. Arsenteva, Elena A. Nikulina, English and French metaphoricallymotivated phraseological units containing religious terms. URL: https://rals.scu.ac.ir/article_15171_57269a1756ea509618817ea52beb0334.pdf 